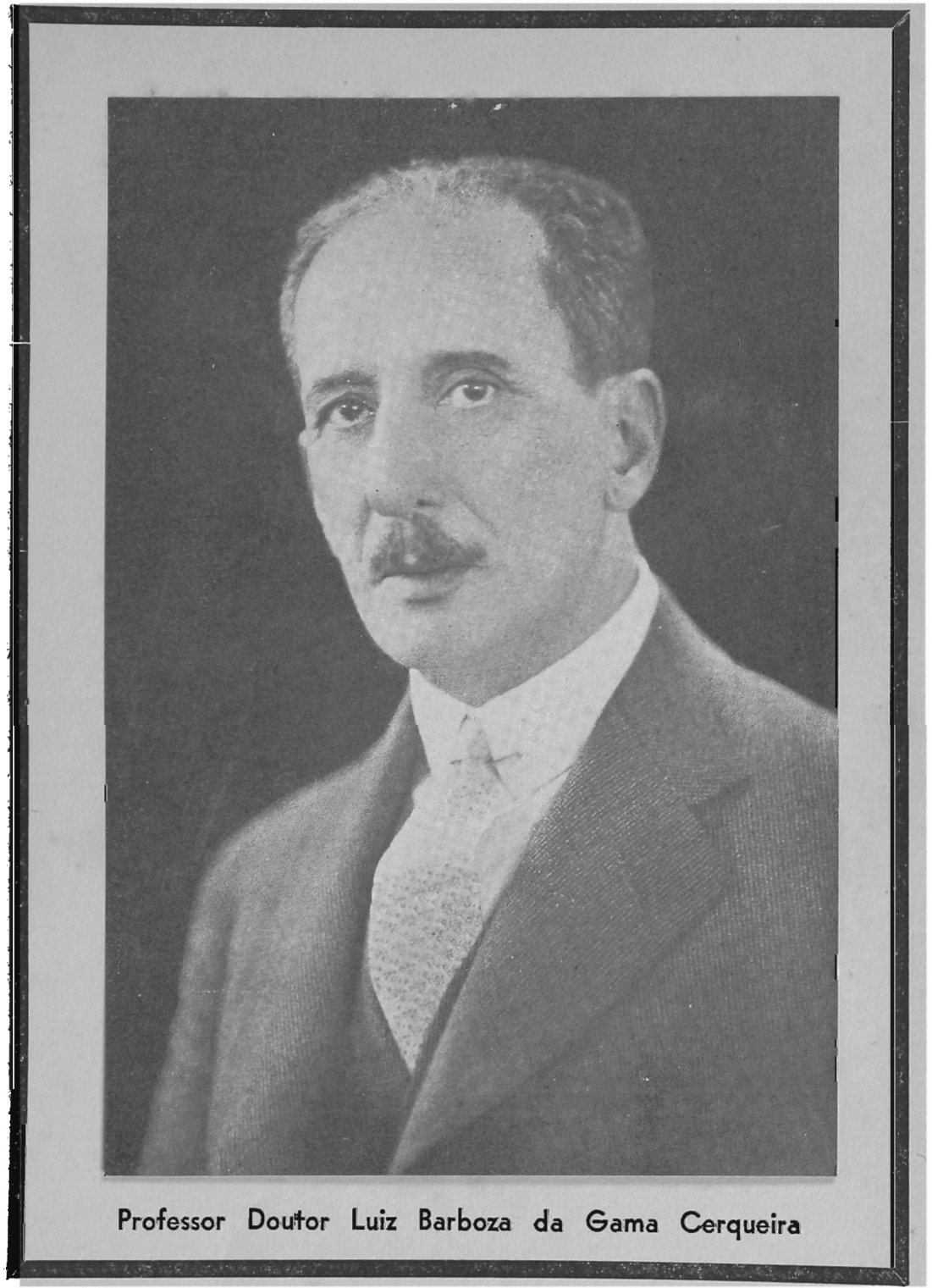




\section{DOUTOR LUIZ BARBOZA DA GAMA CERQUEIRA}

Natural de Paraíba do Sul, Provincia do Rio de Janeiro, onde nasceu a 24 de novembro de 1865 , era o Dr. Luiz Barboza da Gama Cerqueira filho do Conselheiro Francisco Januario da Gama Cerqueira e de Dona Luiza Toledo Barboza Cerqueira.

Depois do curso ginasial, matriculou-se no primeiro ano da Faculdade de Direito de S. Paulo em 1882, recebendo grau de bacharel em ciencias juridicas e sociais em 9 de novembro de 1886.

Formado, retirou-se para S. Josẻ de Além Paraiba, onde exerceu a advocacia e ocupou varios cargos politicos.

Após brilhante concurso, por decreto de 8 de outubro de 1908, foi nomeado professor substituto da $6 .^{a}$ secção desta Faculdade, recebendo o grau de doutor em direito, em virtude dessa nomeação, em 31 desse mês e ano.

Mais tarde, em 1911, foi nomeado professor extraordinario da $4 .{ }^{a}$ secção e, ainda no mesmo ano, passou a ocupar o logar de professor catedrático de Direito Penal, cargo que exerceu até o seu falecimento.

Foi tambem nomeado, por decreto de 8 de junho de 1934, professor de Criminologia do Curso de Doutorado deste Instituto. 
Jurista emerito, advogado notavel, foi o Dr. Gama Cera queira, tambem, politico proeminente. Com Pedro de To ledo, Joaquim Camillo de Brito e Paulo Fonseca, fundou o Partido Republicano Paulista. Eleito deputado pela Constituinte Mineira, depois da proclamação da Republica, renunciou o mandato, em signal de protesto, quando do golpe de estado dado pelo Marechal Deodoro. E, só muito mais tarde, retornou á politica, para fundar com o Conselheiro Antonio Prado e Dr. Francisco Morato, o Partido Democratico de S. Paulo.

Na ultima campanha politica do país, foi eleito deputado federal por S. Paulo, exercendo esse mandato até 19 de fevereiro de 1936, quando a morte o colheu.

Fez parte da comissão elaboradora do projéto do novo Codigo Processual Penal Brasileiro, tendo sido, para esse fim, por ato de 19 de setembro de 1934, comissionado junto ao Ministerio da Justiça e Negocios Interiores. 